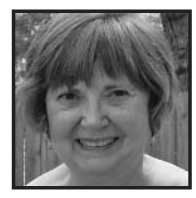

\title{
Commentary:
}

\section{Academia: A Poetic Memoir}

\author{
Laurel Richardson, The Ohio State University
}

\begin{abstract}
A sociological maxim is that one sees from a particular position. As my position in academia changed, I saw differently. In this piece, I offer brief descriptions of my experience in four positions-Untenured Professor, Tenured Associate Professor, Full Professor and Professor Emeritus-and illustrate those with poems written during each of those positions.
\end{abstract}

$\mathrm{n}$ this little text, I want to share with you, the reader, some of the poetry I have written at different times in my academic career. I offer them here, not as great poetry-but as markers of my shifting academic identity, and as an encouragement to you who might be in the throes of academic upheaval, personal or institutional. Any of us might come into academia with a certain set of mind or set of questions and a vision of what we think academia will be like. Many of us find we need to change our minds - if we are not to lose them.

\section{Untenured Professor}

I did my graduate work in sociology with emphases on statistics and social theory. Those specialties gave me an entry into a university position. I was always hired on as temporary or visiting or adjunct, because, in those days, 1962-1970, women faculty were not welcomed into social science departments. 
I was frustrated and angered by my academic situation. I used that frustration to propel my research on gender issues, and expressed my anger in poems. I published my scholarship and my poetry under two different names. Here are two poems from that period:

\section{Even the Knives Sleep}

If I were a fork, I would know my place, to the left of the plate, tines beckoning a hand to cradle me, me holding meat for the knife.

The blade slips between my tines scraping edges.

There is no pain, and after I am bathed in water and returned to the space I share with others of my kind. We nestle together, edges cradling edges. I am safe in the drawer.

Even the knives sleep.

\section{The Men in This Garden Have Rimpled Skin}

Gray, mostly. And slimy. Even now slimy crouched as they are in this garden's nearlight. Haunched. Talking in pulses. Gullets rounded. Bulbous eyed. Secure. Lips half-closed.

I kissed one once:

He became an urban revisionist and a high energy physicist and a resident Zen Buddhist and a motorcyclist, and

He invented a cure for the common gnat and won the Nobel Prize for peace and literature (both in the same year), and 
His lips were cast in bronze, hole bored

in the cleft, strung on golden chains

and worn in a hundred thousand gardens

by gray men in rimpled suits rubbing

Haunches in the after light.

I got warts.

\section{Tenured Associate Professor}

My interest in gender coincided with the social movement for "Women's Liberation." One of my articles, "The Door Ceremony," was featured in the New York Times. A member of the Board of Trustees at my University saw the article when he was in Japan, and he let the provost know that I was "world famous." I was tenured and promoted. And, I merged my two nom de plumes into one, "Laurel Richardson."

Once tenured, I discovered that being an Associate Professor is the most exhausting and demanding job in the university. Institutionally, I could now serve on Important Committees and direct graduate students' dissertations. As one of a small clutch of tenured women, my "service" was widely desired. And internally, I felt that I had been "invited" into the academic world, but I was not "fully" a member. I had to work, work, work. Get grants. Write articles. Here are two poems from that period:

\section{The First Sign of Spring}

a powder beige moth

flying toward me

wing span a full half inch

or less

or more

I didn't look very closely

before I smashed it 


\section{While I Was Writing a Book}

my son, the elder, went crazy

my son, the younger, went sad

nixon resigned

the saudi's embargoed

rhodesia somethinged

and my dishwasher failed

my sister, the elder, hemorrhaged

my brother didn't speak to me

my ex gurued and overdosed

hemlines fell and rose

texans defeated the e.r.a.

and my oil gaskets leaked

my friend, the newest, grew tumors

my neighbor to the right was shot

cincinnati censured sin

and my dracaena plant rotted

I was busy.

\section{Full Professor}

I celebrated becoming a Full Professor. It meant that I was now fully accepted into the academic world. I had made it. No more steps to climb. I felt different; I was treated differently. For me, it became a time to integrate, heal, mentor, do good, say "no" and say "yes." A time to recognize the irony of it all. Here are two of those poems: 


\section{Gem of an Academic Woman}

My

facets

polished

reflect

decades of wisdom

Ground

Beveled

Deflawed

Registered

Certified

Purchased

Displayed in Haggerty Hall,

Room 114D

Tuesdays and Thursdays, 1-3

Not only ivy can climb the walls.

\section{Academia}

(Found Poem, Felix Neck Wildlife Sanctuary)

The Raptor Barn houses

Various Birds of Prey

That are being Rehabilitated

for release. Those that

cannot be released

successfully

are kept

as Educational Birds.

\section{Professor Emeritus}

In my garden, there is a sundial. Carved into it are these words: "Grow old with me. The best is yet to be." That is how I feel about being a Professor Emeritus. I 
invite you all, when your time comes to "grow old with me" and the other released birds. Here is a professor emeritus poem:

Retired Birds

A migration of turacos

A citation of owls

A figment of swans

A pigment of herons

A chance of condors

A branch of jacamars

A goodness of terns

A dressage of penguins

A love of doves

A squawk of hawks

A stark of martins

A carton of larks

What a mighty chorus

Are US! 


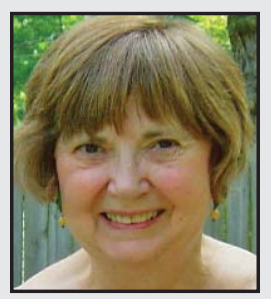

Laurel Richardson is a Professor Emeritus of Sociology at The Ohio State University. She is an internationally renowned qualitative researcher with specialties in gender, arts-based research, and contemporary theory. Her writing crosses the boundaries between the social sciences and the humanities. She is well grounded in theories of knowledge, and well practiced in sharing knowledge through alternative formats, such as poetic representation, dialogue, and essay. Her innovative work has brought her, in recent years, to Denmark, Italy, Canada, Finland, France, Iceland and Australia, as well as to conferences in the United States and to honors for her books, teaching, and community outreach. Her current work is a collection of interlinked essays about "Seven Minutes From Home."

LINKTO:

http://sociology.osu.edu/lwr/ 